\title{
Analysis and Performance Evaluation of Casting Inclusions in the Reactor Coolant Pump Casing of Nuclear Power Plant
}

\author{
Luo Xiaohui ${ }^{1 *}$, Yang Jie ${ }^{2}$, Song $\mathrm{Li}^{1}$, Xu Dezhong ${ }^{1}$ \\ ${ }^{1}$ China Nuclear Power Engineering Co., Ltd., Shenzhen of Guangdong Prov. 518124, China \\ ${ }^{2}$ Suzhou Nuclear Power Research Institute Co., Ltd, Shenzhen of Guangdong Prov. 518120, China
}

\begin{abstract}
The casting quality of the coolant pump casing of the nuclear power plant reactor is directly related to the operational reliability and safety of the nuclear main pump, and plays a key role in the integrity of the pressure-bearing boundary of the reactor primary loop. In this paper, aiming at the low impact performance of the sample during the casting process of the main pump casing of a nuclear power plant, through using failure analysis tools like fishbone diagram from multiple dimensions such as material selection, design and technology, melting analysis, pouring process, riser design, and heat treatment process, and combining with metal macro-fracture analysis and micro-electron microscopy scanning methods for cause analysis, finally, it was found that the basic reason for the low impact performance of the pump shell is that the secondary inclusions appear on the fracture of the sample during the solidification of the molten steel. Using test-retest inspection and finite element mechanics simulation analysis, the comprehensive evaluation of the impact performance of the sample was obtain, which provides an effective solution for the analysis and evaluation of casting inclusions in water pumps of nuclear power plants, and also provides an important reference for the structural optimization and equipment research and development of water pump equipment of nuclear power plants.
\end{abstract}

\section{Introduction}

Nuclear power plant reactor coolant pump (referred to as "main pump"), located between the primary loop reactor and steam generator, is one of the pressure boundaries and key equipment of the reactor coolant system, and it is also the only high-speed rotating equipment in the primary loop main system, of which main function is to drive the cooling medium of the reactor's primary circuit [1]. During the normal power operation of the nuclear power plant, the main pump operates normally to export the core heat and transport it to the steam generator to the secondary side. As the pressure boundary of the primary circuit system, the pump casing has high technical requirements in terms of design pressure, service life, and seismic requirements. On the other hand, due to the complex structure of the pump casing, uneven wall thickness, large outline dimensions, large thermal sections, difficult to feed, high surface roughness requirements, and high requirements for pouring uniformity, structure compactness, which needs to be completed by casting at one time, so its casting is very difficult. In addition, due to the complex casting process and difficult process quality control, special attention should be paid to the rationality of the melting process, pouring system, riser design, and heat treatment during the casting process to avoid shrinkage, loosen and other defects, thus effectively control inclusions.
This paper adopts an analysis method that combines theory and engineering practice to conduct an in-depth analysis of the inclusion problems in the casting process of the main pump casing of the nuclear power plant, and provides an efficient solution and reference for the casting quality control, process improvement and the development of large casting products for the main pump shell.

\section{Introduction to the casting process of pump casing}

The main pump casing of a nuclear power plant is made of cast ferritic-austenitic duplex stainless steel Z3CN2009M. This material has the characteristics of both austenitic and ferritic stainless steel. Compared with ferritic stainless steel, it has higher toughness, lower brittle transition temperature and higher resistance to intergranular corrosion and welding performance ${ }^{[2-4]}$. Compared with austenitic stainless steel, it has higher strength, especially the yield strength is significantly improved, and the performance of resistance to intergranular corrosion, stress corrosion and fatigue corrosion is significantly improved. The material's chemical composition and mechanical performance index requirements are shown in Table 1-2.

\footnotetext{
* Corresponding author: luoxiaohui1985@126.com
} 
Tab.1 Chemical composition requirement of Z3CN20-09M

\begin{tabular}{|c|c|c|c|c|c|}
\hline Element & $\mathbf{C}$ & $\mathbf{S i}$ & $\mathbf{M n}$ & $\mathbf{C r}$ & $\mathbf{N i}$ \\
\hline \multirow{2}{*}{ Content } & $\leq 0.04$ & $\leq 1.50$ & $\leq 1.50$ & $\begin{array}{c}0.19- \\
0.21\end{array}$ & $\begin{array}{c}0.08- \\
0.11\end{array}$ \\
\hline Element & $\mathbf{S}$ & $\mathbf{P}$ & $\mathbf{C u}$ & $\mathbf{B}$ & $/$ \\
\hline Content & $\leq 0.015$ & $\leq 0.03$ & $\leq 1.00$ & $\leq 0.0018$ & $/$ \\
\hline
\end{tabular}

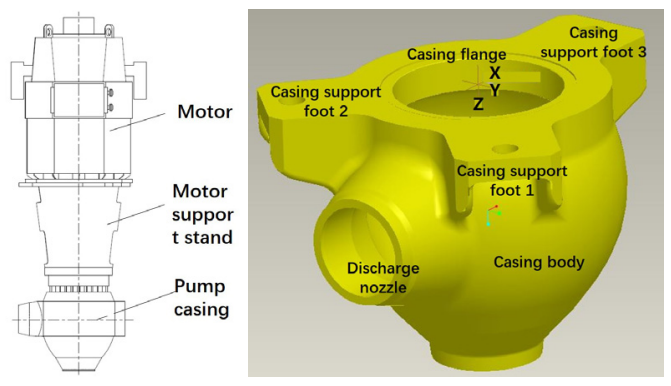

Fig.1 Drawing of Reactor coolant pump and casing

Tab.2 Properties requirement of casing

\begin{tabular}{|c|c|c|}
\hline \multicolumn{3}{|c|}{ Room temperature $\left(23 \pm 5^{\circ} \mathrm{C}\right)$} \\
\hline $\begin{array}{c}\text { Yield } \\
\text { strength }\end{array}$ & $\begin{array}{c}\text { Tensile } \\
\text { strength }\end{array}$ & Elongation \\
\hline Rp0.2(MPa) & Rm(MPa) & $A(5 d)(\%)$ \\
\hline$\geq 210$ & $480-800$ & $\geq 35$ \\
\hline \multicolumn{2}{|c|}{$\begin{array}{l}\text { High temperature } \\
\left(350 \pm 3^{\circ} \mathrm{C}\right)\end{array}$} & $\begin{array}{c}\text { Room temperature } \\
\text { shock }\end{array}$ \\
\hline $\begin{array}{c}\text { Yield } \\
\text { strength }\end{array}$ & $\begin{array}{c}\text { Tensile } \\
\text { strength }\end{array}$ & \multirow{2}{*}{$\operatorname{Akv}(\mathbf{j})$} \\
\hline Rp0.2(MPa) & $\mathbf{R m}(\mathbf{M P a})$ & \\
\hline$\geq 120$ & $\geq 320$ & $\geq 160$ \\
\hline
\end{tabular}

The gross weight of the main pump casing casting is about 44 tons, and the casting requires about 89 tons of molten steel. Due to the large weight of molten steel, the leaked ladle is used for pouring. For fast and stable pouring, open step pouring and multi-layer decentralized internal gates are used to ensure fast, stable, large flowlow flow filling cavity, the top exposed riser is placed for feeding, and through subsidies and cold iron to supplement the water outlet, its pouring schematic diagram is shown in Figure 2. During the impact performance of the pump casing, it was found that the average impact of the two sets of samples was $148 \mathrm{~J}$ and $159 \mathrm{~J}$, which was lower than the specified value of $160 \mathrm{~J}$ as required by the procurement technical requirements. Using the metal fracture analysis, metallographic analysis, macro corrosion test, scanning electron microscopy (SEM) tools and techniques such as finite element analysis simulation computation, this paper analyzes and researches the causes of low impact performance from material selection, design and process, melting, pouring, heat treatment, operation, the external environment of part of the sample, test equipment, and other aspects.
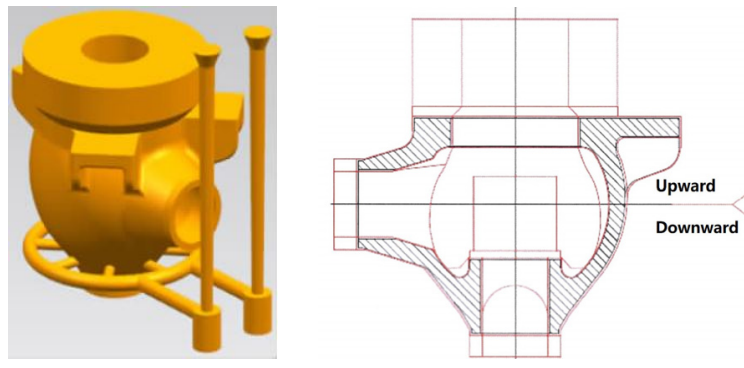

Fig.2 Drawing of Reactor coolant pump casing pouring riser

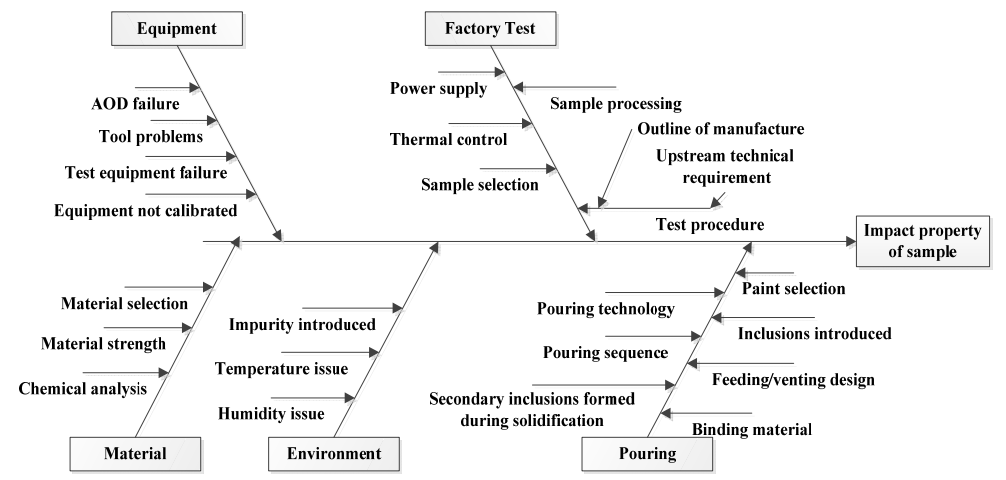

Fig.3 Fishbone diagram of ingot impact properties issue

\section{Fracture analysis}

Visual inspection and macro-corrosion test were carried out on the fracture of the sample with lower impact value. The fracture was smooth, uniform and tidy, and no visible casting defects such as sand holes, pores, slag inclusions, and looseness were found. Therefore, it can be concluded that the low impact average value of the two groups of samples is not caused by any macroscopically visible casting defects, and further microscopic analysis is needed.

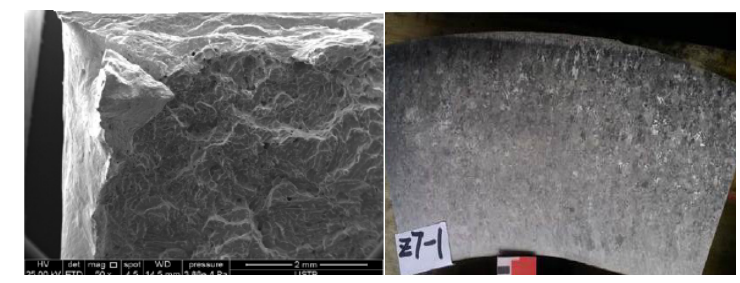

Fig.4 Appearance of fracture and macro-corrosion of casing ingot

Scanning analysis of samples with qualified and low impact performance by electron microscopy revealed 
that the number of secondary inclusions on the specimens with lower impact value is greater than that on the fracture of the specimens with higher impact value, indicating that this secondary inclusion may affect the impact performance of the sample. To further determine the source and cause of the inclusions, based on the analysis of the total amount and particle size of the inclusions, the S-4800 field emission electron scanning microscope was used to perform energy spectrum analysis on the inclusions to identify the types of inclusions and analyze the source. The particles of inclusions are in the micron level. According to the metallographic formation mechanism in the metal smelting and solidification process, the primary alloy phases are usually arranged in a dendritic manner. After it begins to solidify, the remaining liquid will be between the dendrite arms. The front oil edge discharges solute atoms, and the concentration of various solutes will gradually increase, thereby forming secondary inclusions [5-7]. According to the results of scanning electron microscope analysis, the main components of the sample inclusions are completely consistent with the secondary inclusions formed by solute precipitation between dendrites in the solidification front.

Therefore, the lower average impact value of pump shell impact is due to the secondary inclusions formed in the sample fracture during the solidification process of molten steel, which is a random and accidental phenomenon, and does not belong to the foreign inclusions introduced in the process of steelmaking or pouring.
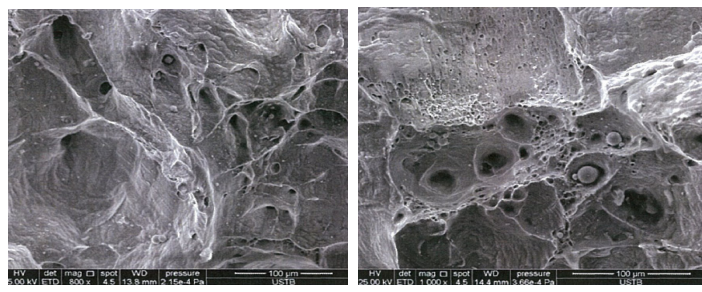

Fig.5 Scanning electron microscope of casing ingot

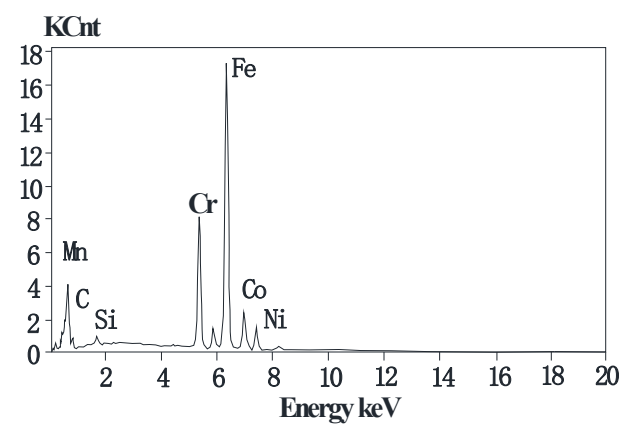

Fig.6 Energy spectrum analysis curve of casing ingot

Tab.3 Energy spectrum analysis data of casing ingot

\begin{tabular}{|c|c|c|c|c|}
\hline Element & $\mathbf{F e}$ & $\mathbf{C}$ & $\mathbf{C r}$ & $\mathbf{N i}$ \\
\hline Content & 51.12 & 24.93 & 16.05 & 5.97 \\
\hline Element & $\mathbf{S i}$ & $\mathbf{C o}$ & $\mathbf{M n}$ & $/$ \\
\hline Content & 1.15 & 0.37 & 0.26 & $/$ \\
\hline
\end{tabular}

\section{Finite element analysis}

The finite element model of the impeller was established through the finite element analysis software ANSYS, and the fluid-solid coupling simulation was carried out. Considering the operating conditions of the main pump, the elastoplastic force school core calculation was performed on the pump casing under normal operating conditions and accident conditions of the pump unit. Establishing a solid model of the impeller through the solid modelling software Pro/E, and importing it into ANSYS, meshing the established geometric model of the pump casing, and considering the irregularity of the pump casing shape, using a three-dimensional 20-node structural solid unit SOLID for intelligent grid division ${ }^{[8]}$. The pump casing model has about 300,000 nodes and 240,000 elements. The centrifugal force load, hydraulic load, pipe load, etc. under design condition, hydraulic test condition and accident condition were applied to the model as input, the Poisson's ratio is 0.3 and elastic modulus is $1.97 \mathrm{e} 5 \mathrm{MPa}$. It can be seen from the simulation calculation results that in the main pump casing design conditions, hydraulic conditions and accident conditions, the maximum stress value is compared with the acceptance stress limit of each working condition, which not only meets the strength design requirements, but also has a larger surplus. Therefore, a small amount of secondary inclusions formed in the solidification process of the pump shell have little influence on the strength calculation of the pump shell from theoretical analysis.

Tab.4 Finite element analysis of pump casing

\begin{tabular}{|c|c|c|c|}
\hline $\begin{array}{l}\text { Working } \\
\text { condition }\end{array}$ & location & $\begin{array}{c}\text { maximum } \\
\text { stress in } \\
\text { Simulation } \\
\text { calculation } \\
\end{array}$ & $\begin{array}{l}\text { Acceptance } \\
\text { stress limit }\end{array}$ \\
\hline \multirow{3}{*}{$\begin{array}{l}\text { Design } \\
\text { conditions } \\
\left(343^{\circ} \mathrm{C}\right)\end{array}$} & $\begin{array}{l}\text { Water inlet } \\
\text { of pump } \\
\text { casing }\end{array}$ & $112.30 \mathrm{MPa}$ & $\begin{array}{c}157.50 \\
\mathrm{MPa}\end{array}$ \\
\hline & $\begin{array}{l}\text { Outlet of } \\
\text { pump } \\
\text { casing }\end{array}$ & $92.42 \mathrm{MPa}$ & $\begin{array}{c}157.50 \\
\mathrm{MPa}\end{array}$ \\
\hline & $\begin{array}{l}\text { Pump } \\
\text { casing }\end{array}$ & $83.06 \mathrm{MPa}$ & $\begin{array}{c}157.50 \\
\mathrm{MPa}\end{array}$ \\
\hline \multirow{3}{*}{$\begin{array}{l}\text { Hydraulic test } \\
\text { conditions } \\
\left(20^{\circ} \mathrm{C}\right)\end{array}$} & $\begin{array}{l}\text { Water inlet } \\
\text { of pump } \\
\text { casing } \\
\end{array}$ & 176.51 MPa & $\begin{array}{c}186.30 \\
\mathrm{MPa}\end{array}$ \\
\hline & $\begin{array}{l}\text { Outlet of } \\
\text { pump } \\
\text { casing }\end{array}$ & $161.43 \mathrm{MPa}$ & $\begin{array}{c}186.30 \\
\mathrm{MPa}\end{array}$ \\
\hline & $\begin{array}{l}\text { Pump } \\
\text { casing }\end{array}$ & $136.10 \mathrm{MPa}$ & $\begin{array}{c}186.30 \\
\mathrm{MPa}\end{array}$ \\
\hline \multirow{3}{*}{$\begin{array}{l}\text { Accident } \\
\text { conditions } \\
\left(348.1^{\circ} \mathrm{C}\right)\end{array}$} & $\begin{array}{c}\text { Water inlet } \\
\text { of pump } \\
\text { casing } \\
\end{array}$ & $156.36 \mathrm{MPa}$ & $\begin{array}{c}252.00 \\
\mathrm{MPa}\end{array}$ \\
\hline & $\begin{array}{l}\text { Outlet of } \\
\text { pump } \\
\text { casing }\end{array}$ & 137.12 MPa & $\begin{array}{c}252.00 \\
\mathrm{MPa}\end{array}$ \\
\hline & $\begin{array}{l}\text { Pump } \\
\text { casing }\end{array}$ & $112.21 \mathrm{MPa}$ & $\begin{array}{c}252.00 \\
\mathrm{MPa}\end{array}$ \\
\hline
\end{tabular}



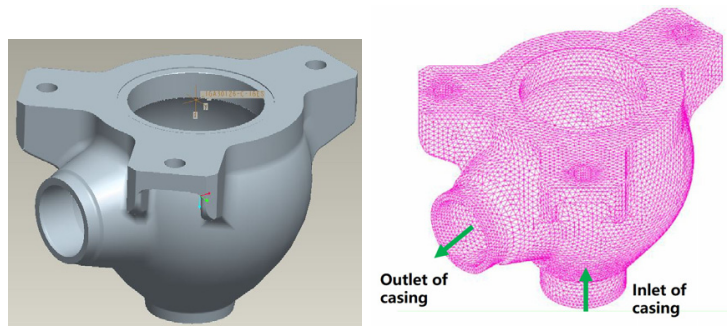

Fig.7 Finite element analysis model of pump casing

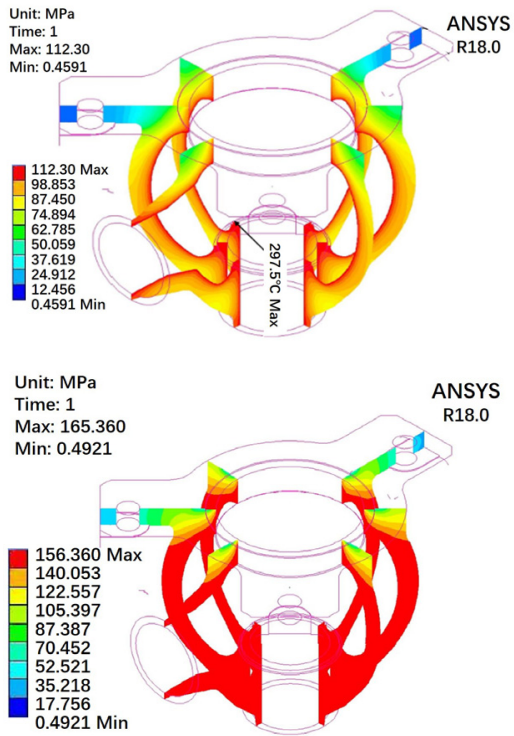

Fig.8 Casing stress analysis in case of design and accident condition

In addition, to verify the casting quality of the pump casing, a hydraulic test was carried out on the pump casing. There was no abnormal phenomenon such as leakage during the test. The global residual deformation rate measured by the hydrostatic test deformation was $4.61 \%$, which met the requirements of the standard. Therefore, during the solidification of molten steel, the occasional phenomenon of secondary inclusions appearing on the fracture surface of the sample will not have a substantial impact on the quality of the pump casing.

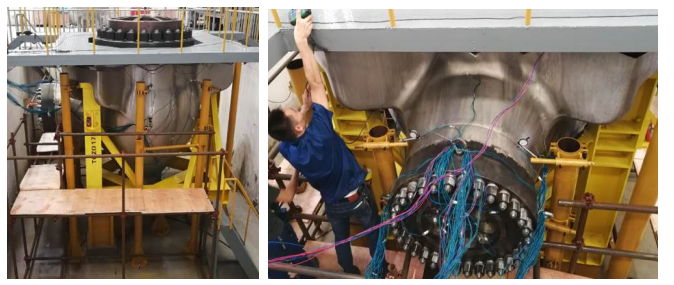

Fig.9 Photos of pump casing's hydro-test

Tab.5 Deformation test result of pump casing's hydro-test

\begin{tabular}{|c|c|c|c|}
\hline Diameter & $\begin{array}{c}\text { Overall } \\
\text { deformation }\end{array}$ & $\begin{array}{c}\text { Residual } \\
\text { deformation }\end{array}$ & Ratio \\
\hline $1-3$ & 75.9 & 2.8 & $3.69 \%$ \\
\hline $2-4$ & 66.6 & 1.9 & $2.85 \%$ \\
\hline $9-11$ & 78.5 & 4.8 & $6.11 \%$ \\
\hline
\end{tabular}

\begin{tabular}{|c|c|c|l|}
\hline $10-12$ & 90.6 & 4.4 & $4.86 \%$ \\
\hline Diameter & $\begin{array}{c}\text { Overall } \\
\text { deformation }\end{array}$ & $\begin{array}{c}\text { Residual } \\
\text { deformation }\end{array}$ & Ratio \\
\hline $13-15$ & 49.1 & 2.6 & $5.30 \%$ \\
\hline $14-16$ & 48.2 & 2.8 & $5.81 \%$ \\
\hline $17-19$ & 38.1 & 1.3 & $3.41 \%$ \\
\hline $18-20$ & 34.3 & 1.6 & $4.66 \%$ \\
\hline Sum of absolute value of overall deformation & 481.3 \\
\hline \multicolumn{2}{|l|}{ Global residual deformation } & 22.2 \\
\hline \multicolumn{2}{|l|}{ Residual deformation ratio } & $4.61 \%$ \\
\hline
\end{tabular}

\section{Optimization and improvement}

Since the secondary inclusions formed during the solidification of molten steel during the casting of the pump casing have a certain degree of randomness and contingency, it is more technically difficult to completely eliminate them by adjusting the pouring process and heat treatment. Therefore, in view of this, the final evaluation can be made by mechanical calculation and other checking means after the sample is qualified in the second test according to the standard requirements ${ }^{[9-10]}$. However, the content of foreign inclusions in the casting process of the pump casing must be strictly controlled. When the content of foreign inclusions exceeds the standard, it will have a greater impact on the mechanical properties of the material. Therefore, by controlling the quality of molten steel and chemical element uniformity, melting process, modelling design, pouring process control, process control, solidification feeding, riser design and pouring process exhaust and slag discharge design constantly optimized, we can control the foreign inclusion content in the process of casting the qualified range, and reduce the pump casing defect rate to ensure the mechanical properties and reliability requirements of the pump casing.

\section{Conclusions and recommendations}

Based on engineering cases, this paper analyses and studies the sources and effects of inclusions in the casting process of the main pump casings of nuclear power plants, which combines fishbone diagram analysis tools, fracture analysis, metallographic analysis, finite element analysis and other analysis methods. The causes and evaluation methods of the pump casing inclusions are analysed in detail, which provides an important reference and reference for the analysis of complex technical problems of other water pump casting raw materials and equipment research and development.
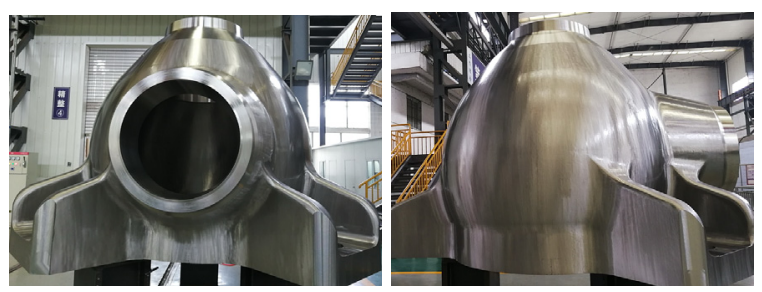

Fig.10 Reactor coolant pump casing after machining process 


\section{References}

1. Guangdong Nuclear Power Training Center. 900MW PWR nuclear power plant system and equipment [M]. Beijing: Atomic Energy Press, 2004.

2. Liu Bing, Meng Xianjia, Wang Yongqin. The relationship between steel casting cracks and inclusions in steel and reduction measures [J]. Foundry Technology, 2005, (10): 854-856.

3. Zhao Maoguo, Xiao Peng, etc. Research on large inclusions in DP590 steel during the casting process [J]. Foundry Technology, 2018, (02): 281-283.

4. Cheng Junwei, Huang Shengcao, etc. Analysis of the causes of non-metallic inclusion defects in iron castings[J]. China Foundry Equipment and Technology, 2016, (05): 34-36.

5. Zhang Chuan, Yu Jin. Design and optimization of casting process for 124D main pump casing based on ProCAST [J]. Large Casting and Forging, 2019, (01): 14-16.

6. Ma Xiaoming, Liao Qingchang. Analysis of failure causes of large cast stainless steel valve bodies [J]. China Foundry Equipment and Technology, 2009 (6): 29-31.

7. Zhang Xinjie, Zhang Huanhuan, Cui Limin. Discussion on Inclusion Control Technology of Austenitic Stainless Steel[J]. China Metallurgy, 2018, (01): 45-48.

8. Shang Xiaojiang, etc., ANSYS. Advanced structural finite element analysis method and example application [M]. Beijing: China Water Power Press, 2008: P120-126.

9. Yang Jiwei, Wang Xuedong, Liu Lian. Development of CAP1400 nuclear main pump casing castings[J]. Foundry Technology, 2018, (04): 812-814.

10. Li Yanbao et al. Analysis of non-metallic inclusions in nuclear-grade austenitic stainless-steel plates for reactor internals[J]. Equipment Machinery, 2015, (02): 59-63. 